\title{
Aspek Hukum dalam Penyelenggaraan Bisnis Perhotelan
}

\author{
Hernawati RAS $^{1^{*}}$, Dani Durahman ${ }^{2}$ \\ ${ }^{1,2}$ Fakultas Hukum Universitas Langlangbuana \\ *Correspondence email: hernawatiras57@gmail.com
}

\begin{abstract}
Abstrak. Pembangunan hukum sebagai bagian dari pembangunan nasional yang dikenal dengan istilah pembaharuan hukum (law reform) dilakukan secara menyeluruh dan terpadu. Usaha perhotelan berkembang pesat seiring dengan perkembangan ekonomi, dalam pembatasan ruang lingkup usaha Hotel diperlukan adanya perangkat hukum yang mengatur mengenaiperizinan dan perlindungan konsumen. Usaha perhotelan yang tidak memiliki izin AMDAL Penegakkan hukum lingkungan dapat dilakukan dengan pemberian sanksi yang berupa sanksi administrasi. Sanksi administrasi, penyelesaian masalah lingkungan diluar pengadilan bahkan sanksi pidana telah diatur dalam UU No. 32 Tahun 2009. Aspek perlindungan terhadap Konsumen Perhotelan harus sesuai dengan ketentuan Undang-Undang Nomor 8 tahun 1999, usaha perhotelan harus memberikan kepastian Hukum dalam memberikan perlindungan terhadap Konsumen dimana pada saat ini masih banyak hotel yang tidak memberikan informasi mengenai hak-hak dan kewajiban Konsumen dan pengembangan tanggung jawab sosial (social responbility).
\end{abstract}

Kata Kunci: Aspek hukum perhotelan

Abstract. The development of the law as part of a national development known as law reform is carried out thoroughly and integratedly. The hospitality business is growing rapidly as the economy develops, within the restrictions on the scope of the Hotel's business, there is a legal device that regulates the permit and protection of consumers. Hospitality businesses that do not have amdal permits Environmental law enforcement can be done by sanctioning administrative sanctions. Administrative sanctions, settlement of environmental issues outside the court and even criminal sanctions have been stipulated in Law No. 32 of 2009. The aspect of protection to Hospitality Consumers must be in accordance with the provisions of Law No. 8 of 1999, hospitality business must provide legal certainty in providing protection to consumers where currently there are still many hotels that do not provide information about consumer rights and obligations and the development of social responsibility (social responsebility).

Keywords: Aspects of hospitality law

\section{PENDAHULUAN}

Indonesia sebagai negara berkembang pada dekade terakhir ini mengalami kemajuan yang cukup pesat, walaupun kemajuan tersebut ditandai masa-masa cukup sulit karena baru saja bangkit dari krisis ekonorni yang berkepanjangan. Secara umum kemajuan yang dicapai oleh bangsa Indonesia dalam berbagai bidang kehidupan tidak diraih begitu saja akan tetapi memerlukan kerja keras serta kerjasama segenap lapisan masyarakat secara menerus serta berkesinambungan.

Masyarakat manusia, betapapun sederhananya, selalu memerlukan penataan dengan pengaturan perilaku di dalam masyarakat, yang kepatuhan dan penegakannya tidak dapat sepenuhnya diserahkan kepada kemauan bebas masing-masing (Ubi societas ibi ius). Karena itu, di dalam masyarakat dengan sendirinya timbul sistem pengendalian sosial (social control) terhadap perilaku para warga masyarakatnya. Dalam perkembangannya, sistem pengendalian sosial ini telah mengalami transformasi, dan memunculkan apa yang sekarang disebut sistem hukum, yang kepatuhan dan penegakannya tidak diserahkan sepenuhnya kepada kemauan bebas masing-masing warga masyarakat, melainkan dapat dipaksakan secara terorganisasi oleh masyarakat sebagai keseluruhan, yakni oleh masyarakat hukum yang pada tingkat perkembangan dewasa ini terorganisasi secara politikal berbentuk badan hukum publik yang disebut negara.

Pembangunan yang dilakukan demi kemajuan Negara Indonesia merupakan pembangunan yang diIakukan secara menyeluruh serta menyentuh segenap aspek hidup masyarakat dalam arti tidak hanya menitikberatkan pada satu bidang tertentu saja. Pembangunan pada bidang ekonomi merupakan penggerak utama membangunan, namun pembangunan ekonomi ini harus disertai upaya saling memperkuat, terkait, serta terpadu dengan pembangunan bidang lainnya.

Aspek hukum, seperti juga halnya aspek estetis, berkaitan dengan dan bertumpu pada aspek ekonomi. Antara kehidupan hukum dan kehidupan ekonomi pertama-tama terdapat suatu hubungan eksternal. Perkembangan dari kehidupan ekonomi adalah landasan bagi perkembangan kehidupan hukum. Hubungan internal ini menampakkan diri dalam unsur ekonomi yuridis (ekonomi hukum). Demikianlah, pembentuk hukum harus melindungi kepentingan-kepentingan hukum dengan cara yang secara yuridis hemat, dan tidak mengabdi suatu kepentingan hukum dengan cara yang eksesif (berlebihan) sehingga merugikan kepentingankepentingan hukum lain yang sederajat atau yang lebih tinggi. Juga ia tidak boleh melampaui batas-batas 
wilayah hukumnya dan dengan demikian merugikan kepentingan-kepentingan hukum. Jika ia melampaui batas wilayah hukumnya, maka dikatakan terjadi "exces de pouvoir" (melampaui kewenangan). Juga unsur ini memperlihatkan sifat yang mandiri dari aspek hukum, tetapi juga mengungkapkan hubungan internal dengan aspek ekonomi tanpa terserap ke dalamnya. Ekonomi yuridis, seperti juga keseimbangan yuridis, adalah suatu asas hukum yang fundamental, yang pada semua bidang hukum harus ikut dipertimbangkan.

Saat ini konsumen dianggap sebagai lahan bisnis oleh para pelaku usaha perhotelan untuk mendapatkan keuntungan yang sebesar-besarnya. Guna mencapai hal ini, para pelaku usaha melakukan cara-cara mulai dari promosi yang gencar, cara-cara penawaran yang tidak wajar bahkan sampai memanfaatkan ketidaktahuan konsumen dan memberikan informasi-informasi yang tidak benar dan menyesatkan terhadap jasa perhotelan

Hukum bisnis adalah badan hukum yang mengatur transaksi bisnis. Usaha Kata menunjukkan suatu kegiatan yang menghasilkan keuntungan. Kegiatan nonprofit bukanlah bisnis, melainkan merupakan amal. Akibatnya, hukum bisnis hanya berhubungan dengan kegiatan yang menghasilkan keuntungan. Hukum bisnis, oleh karena itu, milik hukum perdata daripada hukum publik.

Pembangunan perekonomian yang dibina serta dikembangkan tanpa memperhatikan keseimbangan serta ketertiban akan menciptakan ketidakseimbangan. Oleh karena itu, cukup perlu dibangun serta dibina dengan baik sehingga dapat memberikan sumbangan positif bagi kemajuan bangsa Indonesia. (Richard Burton Simatupang, 1996)

Pengoprasionalan kegiatan usahanya, setiap pelaku usaha hotel harus memiliki izin kegiatan usaha biasanya dalam bentuk Surat Keputusan atau biasanya disebut SK, dimana izin usaha tersebut dikeluarkan oleh pemerintah daerah melalui Peraturan Daerah.

Dampak dari suatu pembangunan hotel yaitu terkait lingkungan. Upaya menegakkan hukum perhotelan tanpa izin dewasa ini memang dihadapkan sejumlah kendala. Pertama, masih terdapat perbedaan persepsi antara aparatur penegak hukum dalam memahami dan memaknai peraturan perundangundangan yang ada. Kedua, biaya untuk menangani penyelesaian kasus lingkungan hidup terbatas. Ketiga, membuktikan telah terjadi perusakan lingkungan diperlukan waktu yang relatif lama dikarenakan dampak perusakan lingkungan baru dirasakan akibatnya dikemudian hari.

Kontrol penataan peraturan ini menjadi penting apabila berkaitan dengan produk yang berhubungan erat dengan kesehatan dan keselamatan manusia, misalnya produk pangan. Tentu tidak perlu menunggu lebih dahulu jatuh korbankeracunan makanan baru kemudian dilakukan pemeriksaan terhadap sarana dan prasarana produksmnya. Akan tetapi, aparat negara yang bertugas dan berwenang untuk ini harus proaktif memeriksa dan mengawasi proses produksi dan pengedaran pangan tersebut.

Hukum dapat kita definisikan sebagai aturanaturan perilaku yang dapat diberlakukan/diterapkan untuk mengatur hubungan-hubungan antar manusia dan antara manusia dengan masyarakatnya. Hukum dapat kita pahami sebagai:

"seperangkat asas dan aturan yang diberlakukan oleh Negara untuk mengatur suatu perilaku dan atau diterapkan oleh hakim untuk menyeIesaikan perkara serta sebagai sarana kontrol soscial dan sarana dalam upaya memenuhi kebutuhan-kebutuhan masyarakat yang secara umum diterima untuk mengusahakan keadilan dan stabilitas". (Henry Campbell, 1990)

Paham yang menempatkan negara memiliki peran dan tugas konstitusional untuk melindungi warga negara saat ini tengah diuji. Saat ini sadar atau tidak, terencana ataupun secara sepontanitas, telah teriibat dalam proses transformasi menuju dunia yang dikuasai oleh kapitalisme aliran neoliberal, disinilah konsep negara kesejahteraan sedang diuji untuk memberikan kesejahteraan bagi warga masyarakat.

Tradisi intervensi negara yang menjadi ciri konsep "welfare state" mengalami perubahan. Isu ekonomi sudah berkembang sedemikian rupa, sehingga timbul harapan dan kekhawatiran sekaligus akan munculnya zaman baru, di mana peran dan keterlibatan organisasi negara sedikit demi sedikit akan kian berkurang dalam banyak aspek kehidupan sosial ekonomi. (Paulee A. Coughlin, 1994)

Asas hukum adalah suatu meta-kaidah yang berada di belakang kaidah, yang memuat kriteria nilai yang untuk dapat menjadi pedoman berperilaku memerlukan penjabaran atau konkretisasi ke dalam aturan-aturan hukum. Dalam dinamika kehidupan hukum di dalam masyarakat, maka asas-asas hukum itu berfungsi untuk menetapkan wilayah penerapan aturan hukum pada penafsiran atau penemuan hukum, sebagai kaidah kritis terhadap aturan hukum, kaidah penilai dalam menetapkan legitimitas aturan hukum, kaidah yang mempersatukan aturan-aturan atau kaidah-kaidah hukum, menjaga/memelihara konsistensi dan koherensi aturan-aturan hukum. Kebertatanan materiil (materiele stelselmatigheid) dalam tata-hukum menunjuk pada tatanan asas-asas hukum yang melandasi dan menjiwai tata-hukum. Tatanan asas-asas hukum itu adalah fundasi dari tata-hukum. Karena itu, asas hukum dapat diidentifikasi dengan menggeneralisasi putusan-putusan hakim dan dengan mengabstraksi dari sejumlah aturanaturan hukum yang terkait pada masalah kemasyarakatan yang sama.

M. Daud Silalahi (2001) yang menyebutkan bahwa penegakan hukum lingkungan mencakup 
penaatan dan penindakan (compliance and enforcement) yang meliputi hukum administrasi negara, bidang hukum perdata dan bidang hukum pidana.

Konsumen memiliki risiko yang lebih besar dari pada pelaku usaha, dengan kata lain hak-hak konsumen sangat rentan (Sudaryatmo, 1999). Disebabkan posisi tawar konsumen yang lemah, maka hak-hak konsumen sangat riskan untuk dilanggar (Vivek Sood, 2002).Terhadap posisi konsumen tersebut, ia harus dilindungi oleh hukum. Karena salah satu sifat, sekaligus tujuan hukum adalah memberikan perlindungan (pengayoman) kepada masyarakat. (Kantohadiprodjo Soediman, 1993). Perlindungan kepada masyarakat tersebut harus diwujudkan dalam bentuk kepastian hukum yang menjadi hak konsumen. (Sinaga Aman, 2001)

\section{METODE}

Metode penelitian yang digunakan adalah metode pendekatan yuridis normatif, yaitu menetapkan standar norma tertentu terhadap suatu fenomena dengan mengkaji data-data sekunder serta membahas implementasi sanksi pidana bagi penegak hukum yang menerima suap dalam menangani perkara dihubungkan UU No. 32 Tahun 2009 Tentang Lingkungan Hidup. Sedangkan analisis data menggunakan metode yuridis kualitatif, yaitu bersumber dari studi kepustakaan dan studi lapangan, kemudian disusun secara sistematis, setelah dianalisa disajikan secara diskriptif. Penelitian lebih menekankan pada kajian analisis data sekunder atau studi kepustakaan yang ditunjang dengan data primer yaitu studi lapangan.

\section{HASIL DAN PEMBAHASAN}

Tiap aturan hukum itu berakar atau bertumpu pada suatu asas hukum, yakni suatu nilai yang diyakini berkaitan dengan penataan masyarakat secara tepat dan adil. Paul Scholten mengatakan bahwa asas hukum adalah pikiran-pikiran dasar yang terdapat di dalam dan di belakang sistem hukum, masing-masing dirumuskan dalam aturan-aturan perundang-undangan dan putusanputusan hakim, yang berkenaan dengannya ketentuanketentuan dan putusan-putusan individual tersebut dapat dipandang sebagai penjabarannya. Jadi, asas hukum itu adalah kaidah yang paling umum yang bermuatan nilaietik, yang dapat dirumuskan dalam tata-hukum atau berada di luar tata-hukum, yang sebagai demikian mewujudkan kaidah penilaian fundamental dalam suatu sistem hukum.

Demikianlah, dari aturan hukum konkret yang mengatur perilaku konkret tertentu dapat diangkat atau diabstraksi sebuah kaidah yang lebih umum yang wilayah penerapannya lebih luas atau lebih umum dari aturan hukum konkret itu tadi. Kaidah yang lebih umum itu dapat diabstraksikan lagi sehingga diperoleh kaidah yang lebih umum lagi yang tentu saja wilayah penerapannya lebih luas lagi. Kaidah pokok atau norma dasar yang paling umum pada bidang kehidupan tertentu yang tidak dapat diabstraksi atau dibuat lebih umum lagi itulah yang disebut asas hukum yang bermuatan nilaietik. Asas hukum adalah dasar umum yang merupakan dasar pikiran atau ratio legis dari kaidah hukum. Jadi, asas hukum adalah rasio-nya dari kaidah hukum positif tertentu, yang secara rasional dapat menjelaskan mengapa kaidahnya itu demikian, apa tujuannya, sejauh mana jangkauan penerapannya. Karena itu, dalam praktek hukum atau penyelenggaraan kehidupan hukum masyarakat, maka asas hukum mengemban dwi-fungsi: sebagai fundasi dari sistem hukum dan sebagai batu-uji kritis terhadap sistem hukum dan aturan hukum.

Asas-asas hukum itu timbul atau berakar pada akalbudi dan nurani manusia. Adanya akalbudi dan nurani itulah yang menyebabkan manusia mempunyai kemampuan untuk membedakan bagus-jelek, baikburuk, adil-tidak adil, dan manusiawi-tidak manusiawi. Kemampuan inilah yang menumbuhkan kesadaran hukum dalam kesadaran manusia, dan kesadaran hukum itulah yang melahirkan asas-asas hukum. Bekerjanya fungsi logikal dalam kesadaran manusia menyebabkan keseluruhan kaidah-kaidah hukum tertata dalam suatu sistem yang menampilkan diri dalam tatanan hukum formal dari tata-hukum yang bertumpu pada tatanan hukum internalnya. Jadi, bekerjanya fungsi logikal dari kesadaran hukum menyebabkan asas-asas hukum secara relatif tertata secara sistemik yang memunculkan kebertatanan internal dalam tata-hukum yang tercermin dalam kebertatanan formal dari tata-hukum tersebut. Fungsi logikal dari kesadaran manusia (nurani dan akalbudi) memungkinkan manusia mempersepsi dan menata keberadaannya sendiri dan dunia realitas di sekelilingnya sehingga dapat dimengerti, bermakna dan mengarahkan perilaku. Demikianlah Paul Scholten menyimpulkan bahwa di antara asas-asas hukum itu terdapat perbedaan tataran berdasarkan derajat keumumannya. Asas-asas hukum yang paling fundamental adalah kaidah-kaidah penilaian yang mewujudkan landasan dari setiap sistem hukum. Scholten mengemukakan adanya lima asas hukum yang termasuk ke dalam kategori ini yang terdiri atas dua pasang yang masing-masing terdiri atas dua asas hukum, dan kedua pasang asas-asas hukum itu didukung oleh satu asas hukum yang kelima. Kelima asas tersebut adalah: pasangan asas kepribadian yang berhadapan dengan asas masyarakat, pasangan asas persamaan berhadapan dengan asas kewibawaan, dan semuanya itu dipelihara keseimbangannya oleh asas pemisahan baik dan buruk. Dalam konteks sistem hukum, kelima asas universal itu diisi dengan asas-asas kebebasan (yang menjadi ideal asas kepribadian) berhadapan dengan cinta-kasih (yang diidealkan oleh asas masyarakat), keadilan (yang diidealkan oleh asas persamaan) berhadapan dengan kepatuhan (yang menjadi ideal asas kewibawaan), yang keseimbangannya dipertahankan oleh pemisahan baik dan buruk. 
Agak berbeda redaksinya dengan definisi di atas adalah definisi asas dan kaidah mengatur hubungan, penyediaan dan penggunaan produk barang dan/atau jasa, antara penyedia dan penggunanya, dalam kehidupan bermasyarakat.bedakan dalam dua kelompok, yaitu hukum ekonomi pembangunan dan hukum ekonomi sosial. Melihat pada kenyataan mi maka tepatlah apa yang dikemukakan oleh Padmo Wahyono bahwa hukum konsumen akan mempunyai kedudukan yang bencorak cross sectorsi (lintas sektonal). (Sunaryati Hartono, 1988)

Pembangunan yang membawa perubahan pesat ini, tentu saja menimbulkan perubahan pada lingkungan. Perubahan pada lingkungan telah melahirkan dampak negatif. Sebagai contoh, pembangunan di sektor perhotelan. Dengan menjamurnya perumahanperumahan yang berdiri di atas lahan-lahan pertanian yang masih produktif membuahkan sempitnya arealareal pertanian, sehingga petani tergerak untuk membuka atau menggarap lahan marginal seperti tanah di tepi sungai, di bukit dan di gunung, serta pembukaan lahan baru di kawasan hutan lindung yang dapat berakibat terjadinya erosi tanah sampai pada tingkat yang mengkhawatirkan. (Arindra CK, 2006)

Pembangunan fisik yang tidak didukung oleh usaha kelestarian lingkungan akan mempercepat proses kerusakan alam. Kerusakan alam tersebut, sebagian besar diakibatkan oleh kegiatan dan perilaku manusia itu sendiri yang tidak berwawasan lingkungan. Untuk itu perlu diupayakan suatu bentuk pembangunan berkelanjutan dan berwawasan lingkungan.

Pembangunan berwawasan lingkungan merupakan upaya sadar dan berencana menggunakan dan mengelola sumber daya secara bijaksana dalam pembangunan yang berkesinambungan untuk meningkatkan mutu hidup. (Harun M. Husein, 1992) Sedangkan pembangunan berkelanjutan (Sustainable Development) didefinisikan sebagai pembangunan yang memenuhi kebutuhan sekarang tanpa mengurangi kemampuan generasigenerasi mendatang untuk memenuhi kebutuhannya sendiri. (Eggi Sudjana dan Riyanto, 1999)

Subjek hukum yang bergerak di sektor dunia usaha perhotelan berperan langsung untuk mencemari atau tidak mencemari lingkungan hidup. Subjek hukum yang bergerak di sektor pendidikan mempunyai peran penting untuk jangka panjang karena akan membentuk manusia yang seutuhnya agar mempunyai wawasan dan kepedulian terhadap lingkungan hidup. Untuk itu diperlukan suatu bentuk pengaturan dan hukum yang tegas.

Undang-Undang No. 32 Tahun 2009 menyediakan tiga macam penegakan hukum lingkungan yaitu penegakan hukum administrasi, perdata dan pidana. Diantara ke tiga bentuk penegakan hukum yang tersedia, penegakan hukum administrasi dianggap sebagai upaya penegakan hukum terpenting. Hal ini karena penegakan hukum administrasi lebih ditujukan kepada upaya mencegah terjadinya pencemaran dan perusakan lingkungan. Di samping itu, penegakan hukum administrasi juga bertujuan untuk menghukum pelaku pencemaran dan perusakan lingkungan.

Salah satu instrumen pelaksanaan kebijaksanaan lingkungan adalah AMDAL sebagaimana diatur dalam Pasal 16 UULH. Sebagai pelaksanaan Pasal 16 UULH, pada tanggal 5 Juni 1986 telah ditetapkan Peraturan Pemerintah No. 29 Tahun 1986 tentang Analisis Mengenai Dampak Lingkungan yang mulai berlaku tanggal 5 Juni 1987 berdasarkan Pasal 40 PP tersebut. (Siti Sundari Rangkuti, 2000)

Sanksi yang memadai) bagi pelaku usaha perhotelan yang membandel dalam pengelolaan limbah sesuai dengan aturan yang berlaku. Jika ada indikasi tindak pidana, aparat penegak hukum dapat menindak tegas para pelaku/penanggung jawab kegiatan seperti diatur dalam Pasal 97-115 UU No. 32 Tahun 2009 tentang Perlindungan dan Pengelolaan Lingkungan Hidup

Melaksanaan peraturan perlindungan konsumen juga menjadi penting dalam kaitannya dengan pemberian hukuman (punishment) atas setiap pelanggaran ketentuan yang berlaku. Pemberian hukuman ini kadang kala menjadi suatu keharusan apabila pelanggaran itu sudah sedemikian rupa saya tidak terulang lagi dan atau pihak lain tidak mengulanginya.

Seperti yang sudah dikemukakan di atas, bahwa akhir-akhir ini muncul istilah hukum ekonomi sebagai nama untuk sekelompok peraturan hukum di bidang ekonomi. Meskipun istilah ini belum diterima dengan sikap yang sama oleh seluruh penguruan tinggi (hukum) di Indonesia, tetapi kenyataannya istilah hukum ekonomi mi makin meluas dikenal. Kalau hukum ekonomi diartikan sebagai keseluruhan penatunan hukum yang benkaitan dengan kegiatan ekonomi dan hubungan ekonomi, hukum perlindungan konsumen, menurut wilayah materinya, tenmasuk ke dalam hukum ekonomi itu.

Hukum ekonomi juga mencakup penelitian mengenai hubungan timbal balik dan sistem ekonomi terhadap sistem hukum dan pengaruh hukum terhadap sistem ekonomi. Akhirnya, hukum ekonomi juga menguji sampai di mana syarat-syarat dan asas manfaat dan kegunaan (doeltreffendheid) yang menjadi pegangan di bidang ekonomi sesuai dan searah dengan nilai-nilai hukum dan keadilan yang tercermin di dalam kaidahkaidah sistem hukum nasional. Mengikuti uraian tentang ruang lingkup hukum ekonomi di atas tampak bahwa hukum tentang perlindungan konsumen termasuk di dalamnya, yaitu bidang hukum ekonomi yang mempersoalkan tentang kaidah-kaidah hukum yang khusus memperhatikan kepentingan umum. Pembagian cakupan hukum ekonomi yang dibuat oleh ELIPS Project, maka mata kuliah hukum perlindungan konsumen adalah salah satu mata kuliah yang termasuk dalam bidang hukum ekonomi. Dan segi materi yang 
dipersoalkan pada hukum perlindungan konsumen, yaitu perlindungan hukum terhadap seseorang dalam kedudukannya sebagai konsumen barang atau jasa, di mana produk ini adalah hasil dan kegiatan ekonomi dan diperoleh melalui hubungan ekonomi maka tepatlah kalau hukum perlindungan konsumen dikelompokkan ke dalam hukum ekonomi.

Pengelompokan seperti ini menurut penulis tidaklah sepenuhnya dapat, karena alasan dititikberatkan pada aspek sosial dan perlindungan konsumen sebab selain aspek sosialnya, pemberian perlindungan kepada konsumen juga bertujuan untuk menjaga eksistensi konsumen itu sendiri sebagai suatu potensi di dalam pembangunan ekonomi, yang berarti melidungi konsumen adalah sama Artinya dengan menjaga kelangsungan produksi. Dengan demikian, selain aspek sosial ekonominya, perlindungan konsumen juga memuat aspek pembangunan. Sehingga kalau mengikuti pembagian hukum ekonomi menurut Sunaryati Hartono (1988), yang terdiri atas hukum ekonomi pembangunan dan hukum ekonomi sosial itu, maka hukum perlindungan konsumen juga masuk ke dalam hukum ekonomi pembangunan.

Terlepas dan perbedaan pandangan di atas mengenai pada kelompok hukum ekonomi yang mana hukum perlindungan konsumen itu dimasukan yang pasti adalah bahwa hukum perlindungan konsumen diterima sebagai bagian dan hukum ekonomi. Dengan menyimak materi hukum ekonomi sebagaimana yang dikemukakan oleh Schrans itu, tampaknya seluruh atau setidaktidaknya sebagian besar dari materi itu dimiliki oleh atau menjadi pokok pembahasan dan hukum perlindungan konsumen uraian-uraian di atas menjadi jelas bahwa hukum perlindungan konsumen meliputi dan termasuk bagian dariseluruh macam-macam menurut pembedabedaan hukum yang dikenal dan sifatnya lintas memakai/dikonsumsi itu. Dengan kata lain, perlu dibuktikan adanyah ubungkausalitas antara perbuatan yang salah dan kerugian yang timbul itu yang mendekati harapan adalah dengan menggunakan pertanggungjawaban khusus sebagaimana dimaksud dalam Pasal 1367 KUH Perdata bahwa seseorang bertanggung jawab atas kerugian yang disebabkan barang yang berada dalam pengawasannya. Persoalannya adalah perlukan penafsiran yang hati-hati dan cermat, yaitu tentang.

\section{SIMPULAN}

Aspek hukum digunakan untuk meneliti kelengkapan, kesempurnaan dan keaslian dan dokumendokumen yang dimiliki mulai dan badan usaha, izin-izin sampai dokumen Iainnya, pelaku usaha perotelan harus memperhatikan dampak lingkungan. Kemudian aspek perlindungan terhadap Konsumen sesuai dengan ketentuan Undang-Undang Nomor 8 tahun 1999, usaha perhotelan harus memberikan kepastian Hukum dalam memberikan perlindungan terhadap Konsumen dimana pada saat ini masih banyak hotel yang tidak memberikan informasi mengenai hak-hak dan kewajiban Konsumen dan pengembangan tanggung jawab sosial (social responbility). Pelaku usaha perhotelan supaya, dalam keadaan excess demand pelaku bisnis perhotelan harus mampu mengembangkan dan memanifestasikan sikap tanggung jawab terhadap masyarakat sekitarnya.

\section{DAFTAR PUSTAKA}

Aman Sinaga, 2001 Pemberdayaan Hak-hak Konsumen di Indonesia, Yayasan Gemainti, Jakarta,

Arindra CK, Melindungi Lingkungan Selamatkan Pembangunan. Dikutip dari situs www. Pikiranrakyat.com/cetak/06-4/05/index.htm, terakhir dikunjungi 24 Agustus 2006

Eggi Sudjana dan Riyanto 1999, Penegakan Hukum Lingkungan dalam Perspektif Etika Bisnis Di Indonesia, Gramedia pustaka utama,

Hartono Sunaryati, 1988, Hukum Ekonomi Pembangunan Indonesia, Binacipta, Bandung

Harun M. Husein 1992, Lingkungan Hidup Masalah Pengelolaan dan Penegakan Hukumnya, Bumi Aksara, Jakarta,

Henry Campbell Black, 1990 Black's Law Dictionary, 'Sixth Ed., West Publishing co., St. Paul Minn.

Kantohadiprodjo Soediman, 1993, Tata Hukum di Indonesia, Cetakan ke-12 (Jakarta: Ghalia Indonesia, 1993)

M. Daud Silalahi, 2001, Hukum Lingkungan Dalam Sistem penegakan Hukum Lingkungan Indonesia, Alumni Bandung,

Paulee A. Coughlin, 1994, "The Movement of Consumer Protection in the European Community: A Vital Link in the Establishment of Free Trade and a Paradigm for North America", International and Competition Law Review, No. 143

Richard Burton Simatupang, 1996, Aspek Hukum dalam Bisnis, Rineka Cipta, Jakarta,

Sudaryatmo, 1999, Hukum dan Advokasi Konsumen. PT Citra Aditya Bakti, Bandung

Siti Sundari Rangkuti, 2000, Hukum Lingkungan Dan Kebijaksaan Lingkungan Nasional, Edisi Kedua, Airlangga University, Surabaya, --, 2009. Undang-undang Republik Indonesia Nomor 32 Tahun 2009 tentang Perlindungan dan Pengelolaan Lingkungan Hidup. Jakarta: Sekretariat Negara

Vivek Sood, Cyber Law Simplified, 2002 (New Delhi: Tata McGaw-Hill Publishing Company Limited. 